Perspective

\title{
Happy Sustainability: A Future Quest for More Sustainable Universities
}

\author{
Kelum A. A. Gamage ${ }^{1}\left(\mathbb{D}\right.$, Nora Munguia ${ }^{2}(\mathbb{D})$ and Luis Velazquez ${ }^{2, *}$ \\ 1 Centre for Educational Development and Innovation, James Watt School of Engineering, \\ University of Glasgow, Glasgow G12 8QQ, UK; kelum.gamage@glasgow.ac.uk \\ 2 Engineering Department, Universidad de Sonora, Hermosillo 83000, Mexico; nora.munguia@unison.mx \\ * Correspondence: luis.velazquez@unison.mx
}

Citation: Gamage, Kelum A. A., Nora Munguia, and Luis Velazquez. 2022. Happy Sustainability: A Future Quest for More Sustainable Universities. Social Sciences 11: 24. https:// doi.org/10.3390/socsci11010024

Academic Editor: Frank Witlox

Received: 8 November 2021

Accepted: 10 January 2022

Published: 13 January 2022

Publisher's Note: MDPI stays neutral with regard to jurisdictional claims in published maps and institutional affiliations.

Copyright: (c) 2022 by the authors. Licensee MDPI, Basel, Switzerland. This article is an open access article distributed under the terms and conditions of the Creative Commons Attribution (CC BY) license (https:// creativecommons.org/licenses/by/ $4.0 /)$.

\begin{abstract}
For decades, sustainability researchers have tenaciously insisted on transforming higher education institutions into more sustainable and inclusive campuses. Yet, as the 2030 agenda seems unlikely to be achieved, universities are struggling to meet the fourth Sustainable Development Goal (SDG 4) before the 2030 deadline. In addition, the post-COVID-19 era demands quality and inclusive education that entails care for students experiencing high stress levels. So far, most of the significant achievements are within the environmental or economic dimensions of sustainable development, but strengthening the social dimension is still one pending task. The importance of happiness to sustainability initiatives on campus, and beyond, deserves further research. To this end, this article offers insights into incorporating the sustainability-happiness nexus into sustainable universities to enhance the social dimension of sustainability. COVID-19 reminds sustainability academics and stakeholders that teaching technical and scientific knowledge is necessary to become more sustainable. Still, it is not sufficient to achieve the goals in the 2030 agenda. Providing inclusive and sustainable quality education will be reached when more sustainable universities consider happiness the ultimate goal of human development.
\end{abstract}

Keywords: higher education institutions; sustainability; happiness; SDG 4; social sustainability

\section{Introduction}

A more sustainable university is an academic topic primarily concerned with higher education institutions engaging in sustainability through a broad and diverse array of strategies focused on preventing, reducing, or eliminating their environmental burden to fulfill its substantive functions of teaching, research, outreach, partnership, and stewardship (Findler et al. 2019). Since its inception, sustainability in campus has been seen as an icon of environmental and economic concerns, but inadequate attention has been paid to the social dimension of sustainable development (Wright 2010; Lozano 2011; Sassen and Azizi 2018). This situation is not a peculiarity of higher education institutions as it also occurs in other settings (Dragun and Jakobsson 1997; Eizenberg and Jabareen 2017).

Education is a critical issue for promoting human development, which is reflected in Sustainable Development Goal 4 (SDG 4). Accordingly, higher education institutions are ultimately responsible for providing inclusive, equitable, and sustainable quality education on campuses. Regrettably, current progress is significantly lagging such that meeting SDG 4 and all of the SDGs is unlikely (United Nations (2020)). Worse yet, the emergence of the COVID-19 pandemic has made it difficult for universities to carry out inclusive and quality education, further reducing the chances of honoring their pledges to contribute to SDG 4. In particular, traditional teaching and face-to-face instruction were essentially canceled and shifted to online instruction, leaving the most vulnerable to lag behind (Pittman et al. 2021; Hörisch 2021). Even students with greater resilience experienced distress because of the many months of lockdowns and the fear of being contagious (Cicha et al. 2021). Moreover, as a consequence of COVID-19 stressors, students are 
experiencing high anxiety levels (Dhar et al. 2020) that have a significant direct impact on their self-perception of happiness (Yildirim and Güler 2021). Concerning the latter, several scholars have suggested that happiness and related constructs are significant predictors of academic performance, having direct implications to SDG 4 (López-Pérez and Fernández-Castilla 2018; Carmona-Halty et al. 2019; Pulido-Acosta and HerreraClavero 2018). In particular, the emergence of COVID-19 has highlighted that teaching technical and scientific knowledge is not the sole necessary condition to become more sustainable; it is not sufficient to achieve the SDGs in the 2030 Agenda. Therefore, the post-COVID-19 era is demanding more novel pedagogical efforts and an emphasis on the social dimension of sustainable development to ensure the continuity of sustainability initiatives, especially SDG 4 . The importance of happiness to sustainability initiatives on campus, and vice versa, deserves further research. This perspective paper argues that incorporating the sustainability-happiness nexus into sustainable universities allows us to better conceptualize and implement the social dimension of sustainability, understanding by nexus any connection between sustainability and happiness in any direction.

\section{Happiness and Sustainability: Conceptualizations}

The terms happiness and sustainability converge on their complexity both when defined and when assessed. Typically, this complexity makes solving a particular sustainability concern more challenging. Hence, solving complex problems requires understanding complexity from a broader perspective that traditional tools of reductionism and specialization cannot offer; therefore, it is recommended to involve specialists in several disciplines to explain the multiple layers of sustainable development (Nilsson 2019). To overcome this particularity, complexity management models exist in the sustainability literature to improve the adaptability of sustainability systems to new circumstances (Espinosa and Porter 2011; Valentinov 2014; Willamo et al. 2018). Furthermore, the ability of relevant stakeholders to respond to problematic situations created at different states of complexity depends on their cognitive complexity; the greater the cognitive complexity, the better the proactive strategic responses to sustainability (Gröschl et al. 2019). While recognizing the importance of coping with the complex and multifaceted nature of sustainability, it is beyond the scope of this article to analyze it more deeply. Thus, this section focuses on how the sustainability-happiness nexus can be evaluated within a sustainable initiative on campus. Towards this end, let us start by exploring different happiness conceptualizations.

Happiness is a subjective feeling that has been conceptualized in different ways (Doh and Chung 2020). For instance, some scholars suggest that there are two types of happiness: the hedonic and eudaimonic, which differ from their premises. The hedonic conceptualization dictates that people should pursue as much pleasure and as little pain as possible and the eudaimonic conceptualization seeks to increase the potential and capacities of human beings or the state of being pleased with one's life (Waterman et al. 2008; Raibley 2012; Joshanloo 2014). In this sense, happiness that stems from direct inputs is known as hedonic happiness and, by contrast, happiness that stems from more lasting experiences is known as eudemonic happiness (Pfeiffer and Cloutier 2016).

Both perspectives, hedonistic and eudaimonic, are associated with the term subjective well-being, which, according to Deci and Ryan (2008), refers to optimal psychological experience and functioning. Furthermore, happiness is also related to and overlaps with life satisfaction (Tandoc and Takahashi 2013). Helliwell and Putnam's (2004) earlier work aimed to clarify that happiness and life satisfaction are indicators of subjective well-being and point out that happiness is indicative of short-term situations and life satisfaction to long-term concerns.

One could accept that a conceptualization of general happiness is one in which an individual is free of cognitive conflicts and biological problems or, at least, can control and positively solve such issues (Hornung 2006). However, there is a stock of literature related to the many different conceptualizations and evaluations of happiness. Broadly, it 
is possible to distinguish between those who prefer subjective assessment and those who like to conduct objective evaluations.

According to Vitrano (2010), subjectivists advocate self-reporting of happiness because they link happiness with a particular mental state characterized as satisfaction or contentment. Further, they assure that subjective information plays an essential role in establishing human development policies (Hirai et al. 2016). On the other hand, most objectivists insist that a happy person meets several criteria or standards that measure personal ideals. Therefore, objectivists trust that happiness data are more appropriate than emotions in measuring human development (Blanchflower and Oswald 2005).

Similarly, sustainability scholars have also had these sorts of debates about sustainable development. For example, the sustainable development concept, coined in 1987 by the World Commission on Environment and Development in the Brundtland Report, raised many critics owing to the lack of clarity about its meaning (Ayres 1993), which, of course, led to several misconceptions (Leal Filho 2000). Moreover, sustainability became an intuitive concept with a minimum technical requirement (Prugh et al. 2000), thus, hard to operationalize. Still, Brundland's concept of sustainable development indeed re-opened the debate to foster a steady-state economy based on preserving natural capital over profits (Daly 1974). The steady-state economic paradigm challenges the tenet of the predominant neoclassic economic theory, substituting natural capital and human-made capital (Costanza and Daly 1992). Agreeing on the steady-state economic theory precepts, promoters of sustainability in several settings focused more on the environmental dimension of sustainable development than on the other two sustainability dimensions (Allenby 1999). Accordingly, Kuhlman and Farrington (2010) suggest assessing the environmental dimension of sustainability separately from one social-economic dimension, which they call the well-being dimension.

The lack of meaning also allowed the concept of sustainability to be used in different contexts and academic fields (Kliucininkas 2001). For example, sociologists started to debate the need to expand the Gross Domestic Product, an essential indicator of a country's overall economic output, as a social sustainability measure at a particular time. Instead, they addressed the need to incorporate the well-being of society as a better sustainability indicator (Heal 2012). In this context, the United Nations Development Program (UNDP) developed the Human Development Index as an alternative to consider people and their capabilities as the ultimate criteria for assessing the development of a country, not economic growth alone (UNDP 2021). Yet, the Human Development Index is not free of criticism. For instance, it has been pointed out that this index finds fault with incorporating the degree of economic and social cohesion in a country (Bilbao-Ubillos 2013). This index has also been criticized for ignoring life satisfaction and other human well-being criteria (Tamburino and Bravo 2021). The Gross National Happiness Index is another alternative development indicator that has captured the interest of scholars, yet it is used just in the small nation of Bhutan (Pillay 2020), which makes its benefits highly uncertain for the vast majority of countries. In general, these frameworks, and others, always generate debate about the availability of reliable and quality data and their wide range of criteria included in each index (Chaaban et al. 2016).

Notwithstanding the varied and somewhat fragmented conceptualizations of happiness and sustainability, there is growing evidence to suggest that sustainable development and happiness are closely linked. Furthermore, this potential link may enable more desirable articulations and ways to implement the social dimension of sustainable development. The next section elaborates on the happiness and sustainability seminal work.

\section{Happiness and Sustainability: Seminal Work}

The study of happiness has involved disciplines from philosophy and psychology to economics, biology, sociology, even theology (Aydin 2012). Yet, the advent of the sustainability-happiness nexus might be associated with the seminal work of $\left(\mathrm{O}^{\prime}\right.$ Brien 2008), who coined the term "sustainable happiness", which is defined as "the happiness that 
contributes to individual, community, and /or global well-being without exploiting other people, the environment, or future generations (p. 290)". According to Zidansek (2007), the causality and directionally of variables comprised in the nexus can be found in both directions. That means that having a positive attitude towards the environment may make people happier. Furthermore, those happy people may hold an array of sustainability beliefs and behaviors to benefit the planet.

Sustainability-happiness studies have been conducted at different scales, national and local, providing evidence of the importance of this topic (Paralkar et al. 2017). For example, Zidansek et al. (2014) reported a positive correlation between happiness and sustainability when happiness was measured in more than one-hundred nations using the Happiness in Nations index or the Life Satisfaction index. In cities and neighborhoods, empirical studies also suggest that self-reported happiness is related to sustainability across several indexes (Cloutier et al. 2014; Souza et al. 2019). On the other hand, some scholars have found higher happiness levels among people with greater environmental knowledge and concerns (Ferrer-i-Carbonell and Gowdy 2007; Membiela-Pollàn et al. 2019). Supporting this premise, Cloutier and Pfeiffer (2015) have theorized a framework about the sustainability-happiness nexus. Another angle of the sustainability-happiness nexus advises that a higher level of air pollution is related to a lower level of happiness (Lin et al. 2019; Zhang et al. 2017).

Other studies, however, find support in the other direction, namely that happiness or the motivation to be happy may drive people to accumulate and consume in unsustainable ways. For example, as individuals obtain material goods, they gain the status of success attached to those materials goods (Manoj et al. 2020). Consequently, they often link their happiness and life satisfaction to those goods and the attainment of more goods (Caliope Sobreira et al. 2020). This purchased-evoked happiness theory is supported by Duan et al. (2021). A recent study also found that people high in materialism sought happiness via extrinsic unsustainable sources (Lee and Ahn 2016). Conversely, Membiela-Pollàn et al. (2019) suggest that rampant materialism makes people less happy.

The main findings from this body of work suggest a lot of potential for researching happiness in new settings (Okulicz-kozaryn 2016).

\section{Happiness and More Sustainable Universities: A Future Quest}

Visioning a more sustainable university has been a recurrent ambition for higher education institutions for nearly three decades (Amaral et al. 2015). For the sake of transparency, rectors and presidents choose to conduct sustainability audits on campus to periodically assess the institution's sustainability performance to compare them against pre-established criteria. As it evolved, different normative frameworks, instruments, and tools emerged as universities attempted to deal with uncertainties in their voluntary sustainability reports and thus to meet critical stakeholders' demands (Shriberg 2002). In this respect, some universities adopted the ISO 14001, an international standard, a framework with generic requirements for an Environmental Management System, as their normative guidance instrument (Price 2005; Velazquez et al. 2013). In addition, over time, specific self-reporting audit frameworks to assess the sustainability of higher education institutions began to appear. Frameworks that have received more endorsement are the Sustainability Tracking, Assessment and Rating System (Urbanski and Filho 2015), the Campus Environmental Audit Response Form (Smith 1993), the Sustainability Assessment Questionnaire (SAQ) (University Leaders for a Sustainable Future (ULSF) (2021)), and the College Sustainability Report Card (Sayed et al. 2013; Ebrahimi and North 2017).

Substantially or moderately, these and other frameworks have contributed to assessing higher education institutions' environmental sustainability performance worldwide. However, none of the current frameworks engage universities to evaluate social and cultural aspects, such as happiness, in their sustainability initiatives in teaching, research, outreach and partnership, or administration (Ribeiro et al. 2016). Moreover, there is currently little 
evidence in the peer-reviewed literature that suggests the inclusion or consideration of happiness into the actual debate about sustainable universities.

Higher education institutions have a historical tradition of creating inter-university collaboration with external society to foster sustainability (Velazquez et al. 2000, 2008). Consequently, most studies relate to societal shifts and trends that determine happiness in a consumer society (Simon-Brown 2000). Regrettably, a few research examples exist in the literature referring to sustainability in campus and happiness. This study reported that students felt happier after participating in an energy initiative on campus (Escobar-Tello and Bhamra 2013). More recently, in a study among Mexican higher education students, the happiest and most academically bright were found to be slightly environmentally sustainable, though more empirical evidence is needed to validate its value (Alves-Pinto and Giannetti 2019; Giannetti et al. 2021).

\section{Remarks}

Universities are struggling to meet SDG 4 before the 2030 deadline. Most of the significant achievements are within the environmental or economic dimensions of sustainable development, but strengthening the social dimension is still one pending task. The post-COVID-19 era demands quality and inclusive education that entails care for students experiencing high stress levels to ensure the continuity of sustainability initiatives. The importance of happiness to sustainability initiatives on campus, and vice versa, deserves further research. To this end, the authors claim that incorporating the sustainabilityhappiness nexus into the actual debate about sustainable universities allows enhancing the social dimension of sustainability.

Throughout this paper, several insights have been offered. First, the authors recognized that there is considerable flexibility in the conceptualizations of both concepts. For example, in the literature, happiness, subjective well-being, and welfare are often terms used interchangeably to define to express the ultimate aspiration for human beings. Similarly, the terms sustainable development and sustainability have been immersed in this kind of semantic debate. Second, the content explored the importance of the sustainabilityhappiness nexus in studies conducted at different scales, suggesting that the causality and directionally of variables in the nexus can be found in both directions. Finally, current audit frameworks to assess sustainability in higher education institutions do not require that universities evaluate social and cultural aspects, such as happiness. In this sense, a promising novel framework for assessing the sustainability-happiness nexus has been initially tested.

Previously, the authors have stated that environmental sustainability systems are usually complex; therefore, escalating complexity by adding happiness criteria to enhance the social dimension of sustainability can lead to disappointment and consequently abandoning sustainability initiatives. On the other hand, sustainability researchers have come a long way since the Brundtland Report and they are better prepared to cope with complexity and assume the challenge of incorporating the sustainability-happiness nexus into sustainable universities. Over time, it is possible to enhance the cognitive complexity of sustainability stakeholders to understand sustainability in a broader sense to incorporate happiness as a relevant factor of the social dimension of sustainability, which might allow both concepts to co-evolve.

As stated above, COVID-19 reminds sustainability academics and stakeholders that teaching technical and scientific knowledge is necessary to become more sustainable. Still, it is not sufficient to achieve the goals in the 2030 agenda. Providing inclusive and sustainable quality education will be reached when more sustainable universities consider happiness the ultimate goal of human development.

Author Contributions: Conceptualization, K.A.A.G., N.M. and L.V.; methodology, N.M. and L.V.; investigation, N.M. and L.V.; resources, K.A.A.G.; writing-original draft preparation, N.M. and L.V.; writing-review and editing, K.A.A.G.; project administration, K.A.A.G.; All authors have read and agreed to the published version of the manuscript. 
Funding: This research received no external funding.

Conflicts of Interest: The authors declare no conflict of interest.

\section{References}

Allenby, Braden R. 1999. Industrial Ecology: Policy Framework and Implementation. Upper Saddle River: Prentice Hall, p. 18.

Alves-Pinto, Marcos José, and Biagio F. Giannetti. 2019. Sustainable Universities: A Comparison of the Ecological Footprint, Hapiness and Academic Performance among Student of Different Courses. In Sustainability on University Campuses: Learning, Skills Building and Best Practices. Edited by Walter Leal Filho and Ugo Bardi. Basel: Springer Nature, pp. 321-38. [CrossRef]

Amaral, Luís P., Nelson Martins, and Joaquim B. Gouveia. 2015. Quest for a Sustainable University: A Review. International Journal of Sustainability in Higher Education 16: 155-72. [CrossRef]

Aydin, Necati. 2012. A Grand Theory of Human Nature and Happiness. Humanomics 28: 42-63. [CrossRef]

Ayres, Robert Underwood. 1993. Industrial Metabolism: Closing the materials cycle. In Clean Production Strategies: Developing Preventive Environmental Management in the Industrial Economy. Edited by Tim Jackson. Boca Raton, Ann Arbor, London and Tokyo: Lewis Publishers, p. 166.

Bilbao-Ubillos, Javier. 2013. The Limits of Human Development Index: The Complementary Role of Economic and Social Cohesion, Development Strategies and Sustainability. Sustainable Development 21: 400-12. [CrossRef]

Blanchflower, David G., and Andrew J. Oswald. 2005. Happiness and the Human Development Index: The Paradox of Australia. Australian Economic Review 38: 307-18. [CrossRef]

Calìope Sobreira, Erica Maria, Clayton Robson Moreira da Silva, and Clàudia Buhamra Abreu Romero. 2020. Do Empowerment and Materialism Influence Slow Fashion Consumption? Evidence from Brazil. Journal of Fashion Marketing and Management: An International Journal 24: 415-35. [CrossRef]

Carmona-Halty, Marcos, Marisa Salanova, Susana Llorens, and Wilmar B. Schaufeli. 2019. How Psychological Capital Mediates Between Study-Related Positive Emotions and Academic Performance. Journal of Happiness Studies 20: 605-17. [CrossRef]

Chaaban, Jad, Alexandra Irani, and Alexander Khoury. 2016. The Composite Global Well-Being Index (CGWBI): A New MultiDimensional Measure of Human Development. Social Indicators Research 129: 465-87. [CrossRef]

Cicha, Karina, Mariia Rizun, Paulina Rutecka, and Artur Strzelecki. 2021. Covid-19 and Higher Education: First-Year Students' Expectations toward Distance Learning. Sustainability 13: 1889. [CrossRef]

Cloutier, Scott, and Deirdre Pfeiffer. 2015. Sustainability Through Happiness: A Framework for Sustainable Development. Sustainable Development 23: 317-27. [CrossRef]

Cloutier, Scott, Lincoln Larson, and Jenna Jambeck. 2014. Between Sustainable Development and Human Well-Being in Urban Areas of the United States. Environment, Development and Sustainability 16: 633-47. [CrossRef]

Costanza, Roberto, and Hernan E. Daly. 1992. Natural Capital and Sustainable Development. Conservation Biology 6: 37-46. [CrossRef]

Daly, Herman E. 1974. The Economics of the Steady State. American Economic Review 64: 15-21.

Deci, Edward L., and Richard M. Ryan. 2008. Hedonia, Eudaimonia, and Well-Being: An Introduction. Journal of Happiness Studies 9: 1-11. [CrossRef]

Dhar, Bablu Kumar, Foster Kofi Ayittey, and Sabrina Maria Sarkar. 2020. Impact of COVID-19 on Psychology among the University Students. Global Challenges 4: 2000038. [CrossRef]

Doh, Young Yim, and Ji Bum Chung. 2020. What Types of Happiness Do Korean Adults Pursue?-Comparison of Seven Happiness Types. International Journal of Environmental Research and Public Health 17: 1502. [CrossRef] [PubMed]

Dragun, Andrew K., and Kristin M. Jakobsson. 1997. Sustainability and Global Environmental Policy: New Perspectives. Cheltenhamand Lyme: Edward Elgar, p. 310.

Duan, Hongbo, Zhilin Huang, Jie Jiang, Xi Ming, Dingxuan Zhang, and Shouyang Wang. 2021. Coronavirus: The Not-So-Trivial Loss of Well-Being. Earth's Future 9: 1-17. [CrossRef]

Ebrahimi, Kianoosh, and Leslie A. North. 2017. Effective Strategies for Enhancing Waste Management at University Campuses. International Journal of Sustainability in Higher Education 18: 1123-41. [CrossRef]

Eizenberg, Efrat, and Yosef Jabareen. 2017. Social Sustainability: A New Conceptual Framework. Sustainability 9: 68. [CrossRef]

Escobar-Tello, M. Carolina, and Tracy Bhamra. 2013. Happiness as a Harmonising Path for Bringing Higher Education towards Sustainability. Environment, Development and Sustainability 15: 177-97. [CrossRef]

Espinosa, Ángela, and Terry Porter. 2011. Sustainability, complexity and learning: Insights from complex systems approaches. The Learning Organization 18: 54-72. [CrossRef]

Ferrer-i-Carbonell, Ada, and John M. Gowdy. 2007. Environmental degradation and happiness. Ecological Economics 60: 509-16. [CrossRef]

Findler, Florian, Norma Schönherr, Rodrigo Lozano, Daniela Reider, and André Martinuzzi. 2019. The Impacts of Higher Education Institutions on Sustainable Development: A Review and Conceptualization. International Journal of Sustainability in Higher Education 20: 23-38. [CrossRef] 
Giannetti, Biagio F., Luis Velazquez, Krystal M. Perkins, Marisela Trillas-Ortiz, Carlos Anaya-Eredias, Feni Agostinho, Cecilia M. V. B. Almeida, Marcos Jose Alves Pinto, and Nora Munguia. 2021. Individual-Level Characteristics of Environmental Sustainability among Students in a Higher Education Institution: The Role of Happiness and Academic Performance. International Journal of Sustainability in Higher Education 22: 1664-90. [CrossRef]

Gröschl, Stefan, Patricia Gabaldon, and Tobias Hahn. 2019. The Co-evolution of Leaders' Cognitive Complexity and Corporate Sustainability: The Case of the CEO of Puma. Journal of Business Ethics 155: 741-62. [CrossRef]

Heal, Geoffrey. 2012. Reflections-Defining and Measuring Sustainability. Review of Environmental Economics and Policy 6: 147-63. [CrossRef]

Helliwell, John F., and Robert D. Putnam. 2004. The Social Context of Well-Being. The Royal Society 359: 1435-46. [CrossRef] [PubMed]

Hirai, Tadashi, Comim Flavio, and Yukio Ikemoto. 2016. Happiness and Human Development: A Capability Perspective. Journal of International Development 28: 1155-69. [CrossRef]

Hörisch, Jacob. 2021. The relation of COVID-19 to the U.N. sustainable development goals: Implications for sustainability accounting, management, and policy research. Sustainability Accounting, Management and Policy Journal 12: 877-88. [CrossRef]

Hornung, Bernd R. 2006. Happiness and the Pursuit of Happiness A Sociocybernetic Approach. Kybernetes 35: 323-46. [CrossRef]

Joshanloo, Mohsen. 2014. Eastern Conceptualizations of Happiness: Fundamental Differences with Western Views. Journal of Happiness Studies 15: 475-93. [CrossRef]

Kliucininkas, Linas. 2001. Assessment of sustainability: Studies at universities and colleges in Lithuania. International Journal of Sustainability in Higher Education 2: 250-56. [CrossRef]

Kuhlman, Tom, and John Farrington. 2010. What Is Sustainability? Sustainability 2: 3436-48. [CrossRef]

Leal Filho, Walter. 2000. Dealing with Misconceptions on the Concept of Sustainability. International Journal of Sustainability in Higher Education 1: 9-19. [CrossRef]

Lee, Michael S. W., and Christie Seo Youn Ahn. 2016. Anti-Consumption, Materialism, and Consumer Well-Being. Journal of Consumer Affairs 50: 18-47. [CrossRef]

Lin, Wen Hsu, Wen Chi Pan, and Chin Chun Yi. 2019. Happiness in the Air? The Effects of Air Pollution on Adolescent Happiness. BMC Public Health 19: 1-10. [CrossRef]

López-Pérez, Belén, and Belén Fernández-Castilla. 2018. Children's and adolescents' conceptions of happiness at school and its relation with their own happiness and their academic performance. Journal of Happiness Studies: An Interdisciplinary Forum on Subjective Well-Being 19: 1811-30. [CrossRef]

Lozano, Rodrigo. 2011. The State of Sustainability Reporting in Universities. International Journal of Sustainability in Higher Education 12: 67-78. [CrossRef]

Manoj, Mrudula, Anjitha Ram Das, and Arun Chandran. 2020. Antecedents of Environmental Engagement and Environmental Learning Behaviour. Journal of Hospitality and Tourism Insights 3: 431-50. [CrossRef]

Membiela-Pollàn, Matías, Maria Allò-Pazos, Carlos Pateiro-Rodrìguez, and Félix Blázquez-Lozano. 2019. The Inefficiency of the Neoclassical Paradigm in the Promotion of Subjective Well-Being and Socioeconomic, and Environmental Sustainability: An Empirical Test for the Spanish Case. Sustainability 11: 7102. [CrossRef]

Nilsson, Fredik Ralf. 2019. A complexity perspective on logistics management: Rethinking assumptions for the sustainability era. The International Journal of Logistics Management 30: 681-98. [CrossRef]

O’Brien, Catherine O. 2008. Sustainable Happiness: How Happiness Studies Can Contribute to a More Sustainable Future. Canadian Psychology 49: 289-95. [CrossRef]

Okulicz-kozaryn, Adam. 2016. Happiness Research for Public Policy and Administration. Transforming Government: People, Process and Policy 10: 196-211. [CrossRef]

Paralkar, Siddhanth, Scott Cloutier, Snigdha Nautiyal, and Ramanuj Mitra. 2017. The Sustainable Neighborhoods for Happiness (SNfH) Decision Tool: Assessing Neighborhood Level Sustainability and Happiness. Ecological Indicators 74: 10-18. [CrossRef]

Pfeiffer, Deirdre, and Scott Cloutier. 2016. Planning for Happy. Journal of the American Planning Association 82: 267-80. [CrossRef]

Pillay, Devan. 2020. Happiness, Wellbeing and Ecosocialism-A Radical Humanist Perspective. Globalizations 17: 380-96. [CrossRef]

Pittman, J., L. Severino, M.J. DeCarlo-Tecce, and C. Kiosoglous. 2021. An action research case study: Digital equity and educational inclusion during an emergent COVID-19 divide. Journal for Multicultural Education 15: 68-84. [CrossRef]

Price, Trevor J. 2005. Preaching What We Practice: Experiences from Implementing ISO 14001 at the University of Glamorgan. International Journal of Sustainability in Higher Education 6: 161-78. [CrossRef]

Prugh, Thomas, Roberto Costanza, and Herman. E. Daly. 2000. The Local Politics of Global Sustainability. Washington, DC: Island Press, p. 15.

Pulido-Acosta, Federico, and Francisco Herrera-Clavero. 2018. Predictores de La Felicidad y El Rendimiento Académico En Una Muestra Multicultural de Adolescentes | I Predictors of Happiness and Academic Performance in a Multicultural Sample of Adolescents. Revista de Estudios e Investigación En Psicología y Educación 5: 9-18. [CrossRef]

Raibley, Jason R. 2012. Happiness Is Not Well-Being. Journal of Happiness Studies 13: 1105-29. [CrossRef]

Ribeiro, Maria Miguel, Elona Hoover, Gemma Burford, Julia Buchebner, and Thomas Lindenthal. 2016. Values as a Bridge between Sustainability and Institutional Assessment: A Case Study from BOKU University. International Journal of Sustainability in Higher Education 17: 40-53. [CrossRef] 
Sassen, Remmer, and Leyla Azizi. 2018. Assessing Sustainability Reports of US Universities. International Journal of Sustainability in Higher Education 19: 1158-84. [CrossRef]

Sayed, Abu, Md. Kamal, and Margret Asmuss. 2013. Benchmarking tools for assessing and tracking sustainability in higher educational institutions: Identifying an effective tool for the University of Saskatchewan. International Journal of Sustainability in Higher Education 14: 449-65. [CrossRef]

Shriberg, Michael. 2002. Institutional Assessment Tools for Sustainability in Higher Education: Strengths, Weaknesses, and Implications for Practice and Theory. International Journal of Sustainability in Higher Education 3: 254-70. [CrossRef]

Simon-Brown, Viviane. 2000. Sustainable Living-Strategies for Breaking the Cycle of Work and Spend. International Journal of Sustainability in Higher Education 1: 290-97. [CrossRef]

Smith, April A. 1993. Campus Ecology: A Guide to Assessing Environmental Quality and Creating Strategies for Change. Venice: Living Planet Press.

Souza, Rose R., Marcos J. Alves-Pinto, Cecília M. V. B. Almeida, Feni Agostinho, and Biagio F. Giannetti. 2019. Calibration of a Questionnaire for Evaluation of Happiness. Journal of Environmental Accounting and Management 7: 449-62. [CrossRef]

Tamburino, Lucia, and Giangiacomo Bravo. 2021. Reconciling a Positive Ecological Balance with Human Development: A Quantitative Assessment. Ecological Indicators 129: 107973. [CrossRef]

Tandoc, Edson C., Jr., and Bruno Takahashi. 2013. The Complex Road to Happiness: The Influence of Human Development, a Healthy Environment and a Free Press. Social Indicators Research 113: 537-50. [CrossRef]

United Nations. 2020. The Sustainable Development Goals Report 2020. Available online: https://unstats.un.org/sdgs/report/2020 /The-Sustainable-Development-Goals-Report-2020.pdf (accessed on 5 April 2021).

UNDP. 2021. Human Development Index (HDI). Available online: http:/ /hdr.undp.org/en/content/human-development-index-hdi (accessed on 1 November 2021).

University Leaders for a Sustainable Future (ULSF). 2021. Sustainability Assessment Questionnaire. Available online: http:/ /ulsf.org/ sustainability-assessment-questionnaire/ (accessed on 5 April 2021).

Urbanski, Monika, and Walter Leal Filho. 2015. Measuring Sustainability at Universities by Means of the Sustainability Tracking, Assessment and Rating System (STARS): Early Findings from STARS Data. Environment, Development and Sustainability 17: 209-20. [CrossRef]

Valentinov, Vladislav. 2014. The Complexity-Sustainability Trade-Off in Niklas Luhmann's Social Systems Theory. Systems Research and Behavioral Science 31: 14-22. [CrossRef]

Velazquez, Luis, Nora Munguia, and Alberto Platt. 2000. Fostering P2 Practices in Northwest Mexico through Inter-University Collaboration. Journal of Cleaner Production 8: 433-37. [CrossRef]

Velazquez, Luis, Nora Munguía, Andrea Zavala, and Maria de los Ángeles Navarrete. 2008. Challenges in Operating Sustainability Initiatives in Northwest Mexico. Sustainable Development 16: 401-9. [CrossRef]

Velazquez, Luis, Nora Munguia, and Monica Ojeda. 2013. Optimizing Water Use in the University of Sonora, Mexico. Journal of Cleaner Production 46: 83-88. [CrossRef]

Vitrano, Christine. 2010. The Subjectivity of Happiness. Journal of Value Inquiry 44: 47-54. [CrossRef]

Waterman, Alan S., Seth J. Schwartz, and Regina Conti. 2008. The Implications of Two Conceptions of Happiness (Hedonic Enjoyment and Eudaimonia) for the Understanding of Intrinsic Motivation. Journal of Happiness Studies 9: 41-79. [CrossRef]

Willamo, Risto, Leena Helenius, Charlotta Holmström, L. Haapanen, Vilma Sandström, E. Huotari, K. Kaarre, U. Värre, A. Nuotimäki, J. Happonen, and et al. 2018. Learning how to understand complexity and deal with sustainability challenges-A framework for a comprehensive approach and its application in university education. Ecological Modelling 370: 1-13. [CrossRef]

Wright, Tarah. 2010. University Presidents' Conceptualizations of Sustainability in Higher Education. International Journal of Sustainability in Higher Education 11: 61-73. [CrossRef]

Yildirim, Murat, and Abdurrahim Güler. 2021. Positivity Explains How COVID-19 Perceiv3d Risk Increases Death Distress and Reduce Happiness. Personality and Individual Differences 168: 110347. [CrossRef] [PubMed]

Zhang, Xin, Xiaobo Zhang, and Xi Chen. 2017. Valuing Air Quality Using Happiness Data: The Case of China. Ecological Economics 137: 29-36. [CrossRef] [PubMed]

Zidansek, Aleksander. 2007. Sustainable development and happiness in nations. Energy 32: 891-97. [CrossRef]

Zidansek, Aleksander, Marko Limbek, and Ivo Šlau. 2014. Contemporary Crises and Sustainability Indicators. Journal of Sustainable Development of Energy, Water and Environmental Systems 2: 100-7. [CrossRef] 